Acta vet. scand. $1973,14,225-228$.

From the State Veterinary Medical Institute, Helsinki, Finland.

\title{
THE EFFECT OF AMPROLIUM AND OF PAYZONE ON THE FUNCTIONAL STATE OF THE THYROID IN GROWING CHICKENS
}

By

P. Andersson and Anna-Stina Garry-Andersson

ANDERSSON, P. and ANNA-STINA GARRY-ANDERSSON: The effect of amprolium and of payzone on the functional state of the thyroid in growing chickens. Acta vet. scand. 1973, 14, 225-228. Amprolium fed to growing chickens in a concentration of 125 p.p.m. in a commercial diet was accompanied by a small but significant decrease in thyroid activity compared with the results for untreated chickens, judged by serum PBI values. The epithelium: colloid relation was lowered. This was presumed to be a consequence of the antagonistic effect of amprolium on thiamine. Payzone feeding, 10 p.p.m. in commercial feed, caused a more pronounced retardation of thyroid activity, judged by the same criteria. A possible connection between the depressed thyroid function and the well-established improvement in weight gain and feed conversion in connection with payzone feeding is discussed.

a mprolium; payzone; thy roid.

The effect of amprolium [1-(4-amino-2-n-propyl-5-pyrimidinylmethyl)-2-picolinium chloride hydrochloride] as a coccidiostat is based upon its chemical resemblance to thiamine, with which it competes for absorption. In tolerance studies on amprolium, Ott et al. (1960) fed chicks for three weeks with 0.01-0.05\% amprolium added to commercial rations and found a mean weight gain of within $0.4 \%$ of the mean weight of the corresponding controls. Olivier et al. (1966), using amprolium in the recommended concentration of $0.0125 \%$ on growing fowl, found no significant differences in body weight, feed consumption and percentage of dry matter retained compared with the results obtained with untreated chickens, but found that the untreated birds tended to be heavier, had a better feed conversion rate and retained a greater percentage of dry matter. Body temperature was not 
affected, but the heavier control group consumed more oxygen, which, they suggested, could be related to the growth rate. In a study on the effect of amprolium $(0.0125 \%)$ on the thyroid gland, Andersson (1970) found a significantly decreased epithelium:colloid (E:C) rate. The thyroids promptly went back to "normal" when amprolium was withdrawn.

Payzone, Nitrovin [1,5-bis (5-nitro-2-furyl) 1,4-pentadien-3-one amidino hydrazone hydrochloride], is a growth-promoting feed additive. The technical data given by the manufacturer (Cyanamid Ltd. 1968) include the statement that, following oral administration, only minute amounts of payzone are absorbed through the intestinal wall. Its mode of action is not fully understood but is presumed to be connected with some limited activity against grampositive bacteria in the intestines. Gerlach (1970) found the numbers of $\mathbf{E}$. coli and lactobacilli in the small intestine increased after payzone feeding. In a study of the thyroid state after continuous feeding of payzone (10 p.p.m.) to growing chicks, Andersson found a clearly decreased E:C relation (unpublished data).

This study was designed to compare the thyroid function in birds given amprolium and payzone respectively.

\section{MATERIAL AND METHODS}

Three groups were set up, each consisting of 10 five-week-old broiler chickens, average weight $810 \mathrm{~g}$. One group was fed a commercial feed without additive, one got amprolium in the form of amprolplus, 125 p.p.m., and the third group had payzone, 10 p.p.m., added to the same basic feed over a period of two weeks. At the end of this time the birds were weighed and blood samples taken in connection with decapitation for PBI-estimation *. The thyroid glands were weighed pair-wise and prepared for histological examination (formol fixation, PAS stain). A histometrical (linear) method was applied and the E:C relation calculated.

\section{RESULTS}

The results are shown in Table 1 . The amprolium chickens had significantly lowered PBI values compared with the controls. In the payzone group the PBI values were still lower. E:C ran parallelly.

\footnotetext{
" “Autotechnicon" autoanalyzer.
} 
T a b l e 1. Average body weight, relative thyroid weight, serum PBI, E: $C$ and feed consumption of chickens fed with amprolium and payzone respectively for two weeks compared with controls.

\begin{tabular}{lccccc}
\hline & $\begin{array}{c}\text { Body weight Thyr. w., mg } \\
\mathrm{g}\end{array}$ & $\begin{array}{c}\text { PBI } \\
/ 100 \mathrm{~g} \text { b.w. } \\
\mu \mathrm{g} / 100 \\
\mathrm{ml}\end{array}$ & E:C & $\begin{array}{c}\text { Feed con- } \\
\text { sumption } \\
\mathrm{g}\end{array}$ \\
\hline Amprolium & 1467 & 16.4 & $0.52^{* *}$ & 0.23 & 1300 \\
Payzone & 1513 & 16.5 & $0.38^{* *}$ & 0.20 & 1700 \\
Control & 1482 & 15.5 & 1.33 & 0.26 & 1700 \\
\hline
\end{tabular}

** Highly significant $(P<0.001)$.

\section{DISCUSSION}

The PBI values of birds fed with amprolium in the concentration of 125 p.p.m. were significantly lowered $(P<0.001)$ compared with the results for untreated birds, as were the $\mathrm{E}: \mathrm{C}$ rates. Amprolium, when added in this concentration to commercial feeds, has repeatedly been found to have no significant effect on body weight. Olivier et al. (1966) even found that untreated birds tended to be heavier and that they consumed more oxygen than amprolium-fed birds. The higher thyroid activity of the untreated birds shown in this study is in accordance with those findings. The antithiamine effect exercised by amprolium in a concentration of $0.0125 \%$ in a well-balanced diet is not significant when body weight is used as a criterion; thyroid activity, however, judged by serum PBI and E: C, is slightly but significantly depressed.

Payzone feeding also depressed thyroid activity significantly and to a higher degree, judged by the criteria applied. Payzone is known to promote weight gain and feed conversion in growing chicks. In his work on thyroid, Ringer (1965) writes in connection with goitrogens: "Depressed thyroid activity is reflected in a reduced metabolic rate which in turn could produce a gain in weight". Is this what is happening in connection with payzone feeding?

\section{REFERENCES}

Andersson, P.: Effekten av kontinuerlig utfodring med Amprolium resp. Zoalen på sköldkörtelns status hos växande kycklingar. (The effect of continued feeding of Amprolium resp. Zoalene on the functional state of the thyroid in growing chicks). Proc. XI. Nord. Vet. Congr., Bergen 1970, 37-40. 
Cyanamid Ltd.: Payzone, growth promoting agent for chickens. Technical information. London 1968.

Gerlach, H.: Zum Verhalten der Darmflora bei Mastküken nach nutritiver Dosierung von Nitrovin. (The behaviour of the intestinal flora in chickens after nutritional administration of Nitrovin). Dtsch. tierärztl. Wschr. 1970, 77, 562-565.

Olivier, A. H., O. J. Stubbs \& C. R. Liebenberg: Influence of coccidiostats on certain physiological processes of the growing fowl. S.Afr. J. agric. Sci. 1966, 9, 917-926.

Ott, W. H., A. M. Dickinson \& A. van Iderstine: Amprolium 3. Tolerance studies in chickens. Poultry Sci. 1960, 39, 1280-1281.

Ringer, R. K.: Avian Physiology. ed. P. D. Sturkie, 2nd Ed., Cornell Univ. Press 1965, 627.

\section{SAMMANFATTNING}

Effekt av amprolium resp. payzone på sköldkörtelstatus hos växande höns.

Amprolium, 125 p.p.m. i kommersiellt foder, orsakade hos växande kycklingar en lindrig men signifikant $(P<0.001)$ sänkning i serum PBJ. Histologiskt förelåg en sänkt epitel:kolloid-relation i sköldkörteln. Amproliums thiaminantagonistiska effekt förmodas vara orsaken till en minskning i sköldkörtelns aktivitet.

Payzone, 10 p.p.m. i samma basfoder, gav en kraftigare sänkning av serum-PBJ och epitel:kolloid-relation. Ett eventuellt samband mellan en sänkt sköldkörtelaktivitet och den väldokumenterade förbättringen i viktökning och foderutnyttjande i samband med payzoneutfodring diskuteras.

(Received January 20, 1972).

Reprints may be requested from: Per Andersson, POB 368, 00101 Helsinki 10, Finland. 